\title{
Finding the Shortest Path to the Hospital in Bogor City using Genetic Algorithm
}

\author{
Mulyati, Irma Anggraeni
}

\begin{abstract}
Bogor city is one of the cities in the province of West Java, there are 13 hospitals located in the region. There are many routes that can be taken to get to the hospital. If there is an emergency or traffic accident, the people has difficult to find which route is closest to the hospital. One of the algorithms used to solve the shortest path is genetic algorithm. Genetic algorithm is an optimization algorithm of simulating biological evolution. By using the concept of biological evolution, it will get the output that is a combination of routes that should be taken to optimize the timing.
\end{abstract}

Index Terms: Genetic Algorithm, Hospital, Shortest Path.

\section{INTRODUCTION}

Bogor city is one of the cities in the province of West Java, there are currently 13 hospitals located in the region [1]. There are many routes that can be taken to get to the hospital. For people who do not really know about the city, if there is an emergency, traffic accident between motorists and others [2], it will be difficult to find which route is closest to the hospital. To find the shortest path can help people reach their destinations faster and more efficiently.

Shortest path problem can be defined as finding the shortest path between two vertices of a directed graph where each arc has been weighted. The shortest path is considered as one of the most fundamental network optimization problems [3]. There are a lot of algorithms used to solve the shortest path problem [4], one of them is genetic algorithm.

Genetic algorithm is a heuristic technique developed by John Holland in 1975 based on genetic and natural selection principles [5]. It is an approach of searching the optimization by simulating natural evolution process. After encoding chromosome, genetic algorithm finds the optimal solution from global view through crossover and mutation of genetic operation [6].

\section{GENETIC ALGORITHM}

Genetic algorithms are search and optimization techniques of genetic processes in the structure of chromosomes of living organisms [7]. For the optimal solution, the genetic algorithm performs a search process among various alternative optimal points based on probabilistic functions [8]. GA starts with generating an initial population by random selection of the individuals named chromosomes. Each chromosome that encodes a

Revised Manuscript Received on April 25, 2019.

Mulyati, Department of Computer Science, Faculty of Mathematics and Sciences, Pakuan University, Indonesia.

Irma Anggraeni, Department of Computer Science, Faculty of Mathematics and Sciences, Pakuan University, Indonesia. candidate solution of the problem is made with a combination of significant genes [9]. The way genetic algorithms work can be seen from Fig. 1.

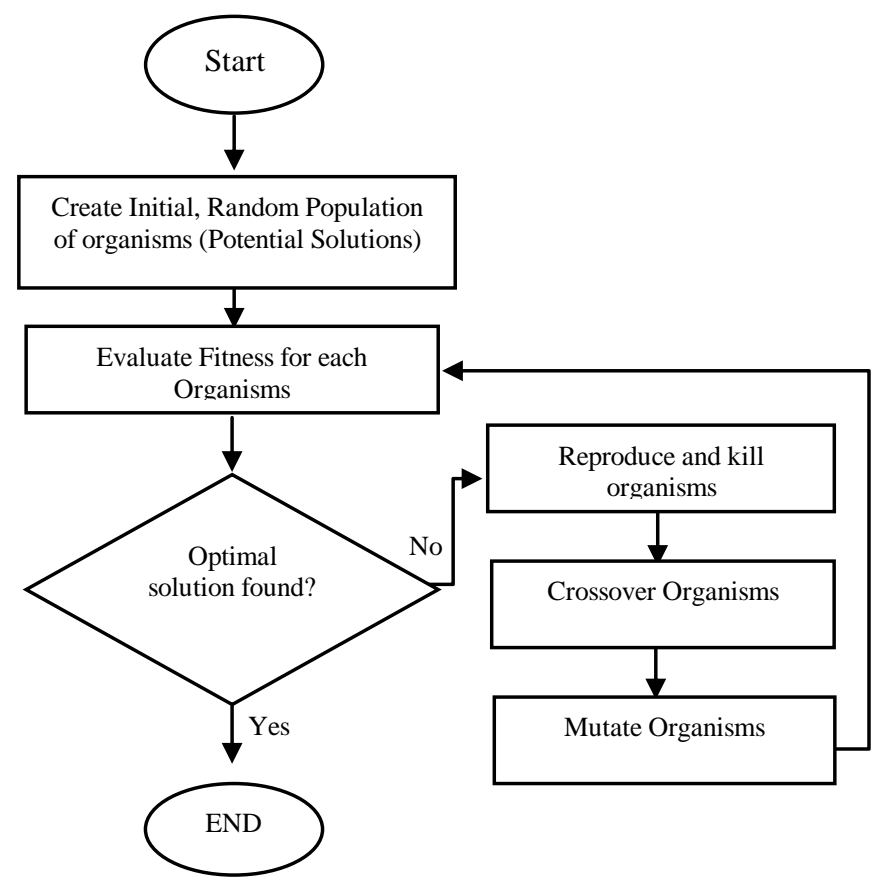

Fig. 1. Flowchart of Genetic Algorithm

Based on Fig. 1. The steps of genetic algorithm:

\section{A. Initialization}

Each gene of a chromosome is a randomly generated real value. Set of genes will be the population, this population is the beginning of the solution.

\section{B. Evaluate fitness}

Each member of the population is evaluated using fitness value. Individuals with the best value fitness will survive while the low value ones will die. Each path in the initial population is calculated distance, fitness value, and cumulative probability:

1) Finding the distance of each path $\left(Z_{i}\right)$

2) Find the total distance from the entire path

$$
\sum_{i=1}^{N} Z_{i}
$$


3) Looking for the fitness value of each path $\left(F_{i}\right)$

$$
F_{i}=\frac{\sum_{i=1}^{N} Z_{i}}{Z_{i}}
$$

4) Find total fitness

$$
\sum_{i=1}^{N} F_{i}
$$

5) Finding the probability of each path $\left(P_{i}\right)$

$$
P_{i}=\frac{F_{i}}{\sum_{i=1}^{N} F_{i}}
$$

6) Finding the cumulative probability of each path $\left(q_{i}\right)$

$$
q_{1}=\sum_{k-1}^{i} P_{i}
$$

\section{RESULT AND DISCUSSION}

The shortest path search is to get to each hospital using Genetic algorithm. The distance between each node is searched with the help of Google maps directions application.

\section{A. Solving Steps with Genetic Algorithms}

Let $\mathrm{P}$ (generation) be the population of a generation, then simply the genetic algorithm consists of steps:

1) $[$ Start $]$ Generation $=0$

2) Population initialization, at random.

3) [Fitness] search for fitness and probability on each chromosome.

4) [Replace] do process repetition as much as chromosome in population.

5) [Selection] compare all probability values up to the smallest value.

6) [Test] if final condition is met then stops and show solution and population.

\section{B. Route Search Testing}

In this test, we will see the results of manual calculations with genetic algorithm, whether it is in accordance with the implementation that is displayed by the system. In this route search implementation we will find the closest route from the starting point using the yellow marker $\mathrm{X}$ as the starting point symbol, to the red $\mathrm{P}$ marker as the destination point, it can be seen from Fig. 2.

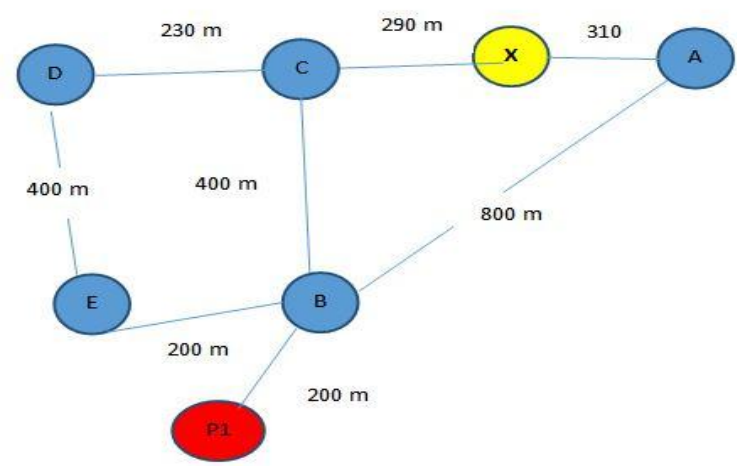

Fig. 2. Route from the starting point $X$ to $P$
Based on the above graph can be a search for the shortest path:

1) Generation $=0$

2) Initial Population is $X-A-B-C-D-E-P$

a. Chromosome / Line 1: $\mathrm{X}-\mathrm{A}-\mathrm{B}-\mathrm{P}$

b. Chromosome / Line 2: X- C - B - P

c. Chromosome / Line 3: X- C - D - E - B - P

3) The fitness and probability values of each chromosome:

a. Chromosome 1: X-A - B - P

Distance each path

$$
\begin{aligned}
& A=310 \\
& B=400 \\
& P=200
\end{aligned}
$$

i. Total Distance of all paths

$$
\begin{aligned}
& =(A+B+D+P) \\
& =310+400+200 \\
& =910 \text { Meter }
\end{aligned}
$$

ii. The fitness value of each path

$$
\begin{aligned}
& f_{i}=\frac{\sum_{i=1}^{N} Z_{i}}{Z_{i}} \\
& f_{1}=\frac{910}{910}=2.93, \\
& f_{2}=\frac{910}{200}=4.55 \\
& f_{a}=\frac{910}{400}=2.275
\end{aligned}
$$

iii. Total fitness

$$
\begin{aligned}
& =f_{1}+f_{2}+f_{3} \\
& =2.93+4.55+2.275 \\
& =9.755
\end{aligned}
$$

iv. Probability of each path

$$
P_{1}=\frac{2.99}{9.755}=0.300
$$$$
P_{2}=\frac{4.55}{9.75}=0.467
$$$$
P_{a}=\frac{2.275}{9.755}=0.23
$$

v. Cumulative probability of each path

$$
\begin{aligned}
& =P_{1}+P_{2}+P_{3} \\
& =0.300+0.467+0.23 \\
& =0.997
\end{aligned}
$$

b. Chromosome / Line 2: X- C - B - P

Distance each path

$$
\begin{aligned}
& C=400 \\
& B=400 \\
& P=200
\end{aligned}
$$

i. Total Distance of all paths

$$
\begin{aligned}
& =X+C+B+\mathrm{P} \\
& =400+400+200 \\
& =1000 \text { meter }
\end{aligned}
$$

ii. The fitness value of each path

$$
\begin{aligned}
& f_{1}=\frac{1000}{400}=2.5 \\
& f_{2}=\frac{1000}{400}=2.5 \\
& f_{a}=\frac{1000}{200}=5
\end{aligned}
$$


iii. Total fitness

$$
\begin{aligned}
& =f_{1}+f_{2}+f_{2} \\
& =2.5+2.5+5 \\
& =10
\end{aligned}
$$

iv. Probability of each path

$P_{1}=\frac{2.5}{10}=0.25$

$P_{2}=\frac{2.5}{10}=0.25$

$P_{\mathrm{a}}=\frac{5}{10}=0.5$

v. Cumulative probability of each path

$$
\begin{aligned}
& =P_{1}+P_{2}+P_{a} \\
& =0.25+0.25+0.5 \\
& =1
\end{aligned}
$$

c. Chromosome / Line 3: X- C - D - E - B - P

Distance each path

$$
\begin{array}{ll}
C=290 & E=400 \\
D=230 & B=200 \\
P=200 &
\end{array}
$$

i. Total Distance of all paths

$$
\begin{aligned}
& =\mathrm{X}+C+E+B+P \\
& =290+400+230+200 \\
& =1120 \text { meter }
\end{aligned}
$$

ii. The fitness value of each path

$$
\begin{aligned}
& f_{1}=\frac{1120}{290}=3.862 \\
& f_{2}=\frac{1120}{400}=2.8 \\
& f_{1}=\frac{1120}{220}=4.8695 \\
& f_{4}=\frac{1120}{200}=5.6
\end{aligned}
$$

iii. Total fitness

$$
\begin{aligned}
& =f_{1}+f_{2}+f_{2}+f_{4} \\
& =3.862+2.8+4.8695+5.6 \\
& =17.1315
\end{aligned}
$$

iv. Probability of each path

$$
\begin{aligned}
& P_{1}=\frac{a .862}{17.1715}=0.2254 \\
& P_{2}=\frac{\frac{12.8}{17.1915}}{17.13}=0.163 \\
& P_{a}=\frac{4.8695}{17.915}=0.2842 \\
& P_{4}=\frac{5.6}{17.1315}=0.326
\end{aligned}
$$

v. Cumulative probability of each path

$$
\begin{aligned}
& =P_{1}+P_{2}+P_{a}+P_{4} \\
& =0.2254+0.163+0.2842+0.326 \\
& =0.9986
\end{aligned}
$$

4) Compare the cumulative probability of each chromosome
a. Chromosome $1=0.997$
b. Chromosome $2=1$
c. Chromosome $3=0.998$

5) The best result is chromosome 1 because it has the smallest probability value is 0.997 then the process is stopped.

The path can be explained that in the search for the shortest distance with the criteria:
Chromosome $1=910$ meters

Chromosome $2=1000$ meters

Chromosome $3=1120$ meters

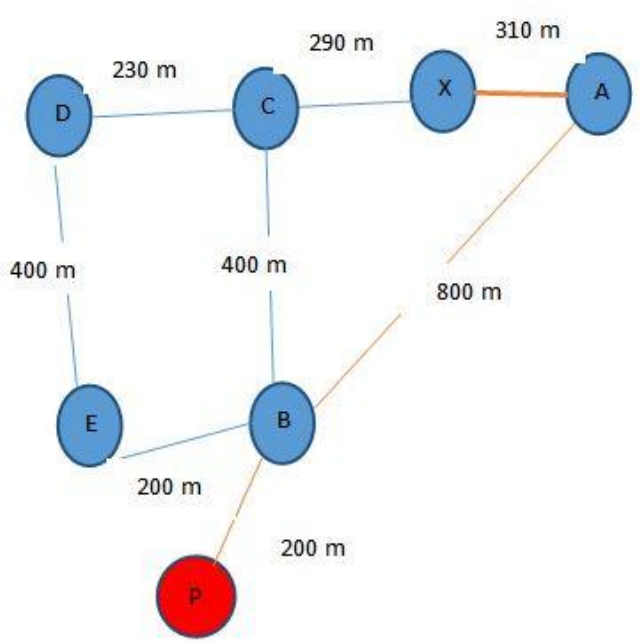

Fig. 3. The result of the route search by genetic algorithm of route $X$ to $P$

based on figure 3 the result the closest search path that starts from the point $\mathrm{x}$ and the end point $\mathrm{P}$ using the genetic algorithm the shortest path is obtained by line X-A - B - P.

\section{CONCLUSION}

This paper proposes a genetic algorithm to determine the shortest path. Based on the results and discussion it can be concluded that the genetic algorithm is able to determine the closest route to the hospital in Bogor.

\section{REFERENCES}

1. H. W. Nugraha. "Penerapan Algoritma Ant Colony pada Pencarian Rute terdekat rumah sakit dikota bogor berbasis Android", Bachelor Thesis, Bogor: Pakuan University. Bogor, 2017.

2. Rendio Halda, Ahmad Yani Ranius, Hadi Syaputra,"Implementasi Algoritma Dijkstra Untuk Menentukan Jalur Terpendek Rumah Sakit Di Kota Palembang", Bachelor Thesis, Palembang: Universitas Bina Darma, 2015.

3. U. Atila, I. R. Karas, C. Gologlu, B. Yaman, and I. M. Orak,"An Idea for Finding the Shortest Driving Time Using Genetic Algorithm Based Routing Approach on Mobile Devices", International Journal of Mathematics annd Computers in Simulation, vol. 6, no. 1, pp. 9 -16, 2012.

4. B. Amaliah, C. Fatichah and O. Riptianingdyah, "Finding the shortest paths among cities in Java Island using node combination based on dijkstra algorithm", International journal on smart sensing and intelligent systems, vol. 9, no. 4, pp. 2219-2236, 2016.

5. J. H. Holland, Adaptation in natural and artificial system, United States: University of Michigan Press, 1975.

6. L. Shimin and W. Zhangang, "Genetic Algorithm and its Application in the path-oriented test data automatic generation", Procedia Engineering. vol. 15 , pp. $1186-1190,2011$.

7. D. E. Goldberg,. "Genetic Algorithm in Search Optimization and Machine Learning”, Boston: Addison Wesley, 1989.

8. Z. Michalewicz, "Genetic algorithms Data Structures Evolution Programs", Heidelberg: Springer-Verlag, 1996.

9. D. Whitley, "A genetic algorithm tutorial. Statistics and Computing”, Vol. 4 , no. 2 , pp. $65-85,1994$. 